ISSN: 1858-4837; E-ISSN: 2598-019X

Volume 15, Nomor 1 (2020),

https://jurnal.uns.ac.id/region

DOI: 10.20961/region.v15i1.23186

\title{
Hubungan pemanfaatan lahan dengan volume pergerakan di Jalan Margonda Raya, Kota Depok
}

\author{
The correlation of land uses and traffic volume in Jalan Margonda Raya, Kota \\ Depok
}

\author{
O Anggraeni ${ }^{1}$, W Astuti ${ }^{1}$, dan H Mukaromah ${ }^{1}$ \\ ${ }^{1}$ Program Studi Perencanaan Wilayah dan Kota, Fakultas Teknik, Universitas Sebelas \\ Maret
}

Corresponding author's email: oktianggraeni@gmail.com

\begin{abstract}
Abstrak. Jalan Margonda Raya merupakan jalan arteri yang sekaligus berfungsi sebagai jalan utama di Kota Depok, Jawa Barat. Koridor jalan tersebut merupakan salah satu kawasan yang mengalami perkembangan pemanfaatan lahan akibat adanya Universitas Indonesia (UI). Perkembangan pemanfaatan lahan di kawasan tersebut berorientasi memenuhi kebutuhan mahasiswa sehingga mengakibatkan fungsi pemanfaatan lahan di sepanjang koridor Jalan Margonda Raya menjadi beragam. Pemanfaatan lahan yang beragam membangkitkan pergerakan penduduk dari satu tempat ke tempat lainnya dalam upaya pemenuhan kebutuhan yang juga mempengaruhi volume pergerakan di koridor tersebut. Berdasarkan fenomena tersebut, penelitian ini dilakukan dengan tujuan untuk mengetahui hubungan pemanfaatan lahan dengan volume pergerakan di Jalan Margonda Raya, Kota Depok. Data yang dikumpulkan dalam penelitian ini berdasarkan observasi lapangan dan traffic counting pada 32 titik. Data tersebut selanjutnya di analisis mengunakan teknik pemetaan dan statistik deskriptif untuk mengetahui jenis dan luasan pemanfaatan lahan, volume lalu lintas untuk mengetahui volume pergerakan, serta korelasi dan deskripsi untuk mengetahui hubungan dan karakteristik. Hasil penelitian menunjukan bahwa terdapat hubungan yang kuat antara pemanfaatan lahan dengan volume pergerakan yang terjadi pada koridor Jalan Margonda Raya. Hubungan kuat tersebut menunjukkan karakteristik bahwa semakin luas pemanfaatan lahan pada kawasan penelitian, aktivitas yang terjadi pada pemanfaatan lahan tersebut semakin beragam sehingga menyebabkan tingginya volume pergerakan.
\end{abstract}

Kata Kunci: Hubungan; Korelasi; Pemanfaatan Lahan; Sistem Transportasi; Volume Pergerakan

Received: August 25, 2018; Accepted: September 09, 2018; Available online: January 10, 2020

Copyright $\odot$ 2020, REGION: Jurnal Pembangunan Wilayah dan Perencanaan Partisipatif 


\begin{abstract}
Jalan Margonda Raya is an arterial road which also serves as the main road in Depok, West Java. This road corridor is one of the areas where land use has developed due to the existence of Universitas Indonesia (UI). The land use development is oriented to meet the needs of collage students, resulting the land use along Jalan Margonda Raya corridor to be varies. The diverse land use increasing mobility from one to another place in order to meet people's need, which also affects the traffic volume in the corridor. Based on this phenomenon, this research aim to determine the correlation of land use and traffic volume in Jalan Margonda Raya, Depok. In this research, the data is based on field observations and traffic counting at 32 points. Analysis techniques used in this research are mapping and descriptive statistic techniques to determine the type and width of land use; traffic volume to find out the volume of mobility; correlation and description to find out the relationship and characteristics. The result shows that there is a strong correlation between land use and traffic volume on Jalan Margonda Raya corridor. It shows characteristic that the wider land use in the research area, the more diverse activities that occur, thus causing a high traffic volume.
\end{abstract}

Keywords: Correlation; Land Use; Relationship; Traffic Volume; Transportation System

\title{
1. Pendahuluan
}

Pemanfaatan lahan dan sistem transpotasi pada lingkungan perkotaan saling mempengaruhi satu sama lainnya. Perkembangan pada salah satu aspek akan menyebabkan perkembangan pada aspek lainnya [1]. Kota Depok sebagai salah satu kawasan metropolitan Jabodetabek mengalami perkembangan yang sangat pesat. Perkembangan bisa dilihat dari jumlah penduduk Kota Depok yang mengalami peningkatan sebesar 25,5\% pada tahun 2016 , dari jumlah 1.736.565 jiwa pada tahun 2011 dengan laju pertumbuhan penduduk 4,54\% [2-3]. Secara spasial, perkembangan pesat yang terjadi di Kota Depok dimulai ketika Universitas Indonesia (UI) sebagai lembaga pendidikan berpindah lokasi dari Jakarta ke Depok sekitar pertengahan tahun 80-an [4]. Keberadaan UI merupakan bentuk dari peningkatan kegiatan pada kawasan sekitarnya dan menjadikan daya tarik kawasan. Banyaknya migrasi masuk menjadikan kawasan sekitar UI berubah menjadi kawasan dengan pemanfaatan lahan untuk menunjang kebutuhan para migran, khususnya mahasiwa UI [4]. Hal ini menjadikan pemanfaatan sekitar UI menjadi beragam.

Pemanfaatan lahan di sekitar kawasan perguruan tinggi memiliki karakteristik untuk memenuhi kebutuhan mahasiswanya. Menurut Amiruddin, pemanfaatan lahan sekitar kawasan perguruan tinggi berfungsi untuk permukiman, perdagangan dan jasa, kesehatan, rekreasi, dan pemanfaatan lahan penunjang lainnya berupa RTH [5]. Menurut Munggiarti \& Buchori, pemanfataan lahan sekitar kawasan perguruan tinggi memiliki karakteristik seputar untuk rumah tinggal, indekos, dan tempat usaha [6]. Sedangkan menurut Pratiwi \& Ihsannudin, pemanfaatan lahan sekitar kawasan perguruan tinggi meliputi perumahan, kuliner, jasa, pendidikan, peribadatan, dan halte [7].

Keberagaman pemanfaatan lahan suatu kawasan selanjutnya akan meningkatkan volume pergerakan pada jalannya [8]. Volume pergerakan diukur dari banyaknya kendaraan dalam 
periode waktu tertentu melintas pada arus jalan tertentu dalam satuan kendaraan per satuan waktu [9]. Pemanfaatan lahan yang semakin luas mengakibatkan lebih banyak aktivitas yang ada didalamnya, sehingga dapat berpengaruh terhadap volume pergerakannya [10]. Semakin besar pemanfaatan lahan pada suatu kawasan, maka volume pergerakan yang dihasilkan juga akan semakin besar [11]. Sehingga volume pergerakan dengan pemanfaatan lahan memiliki korelasi yang positif [10].

Perkembangan pesat yang terjadi pada pemanfaatan lahan di suatu kawasan memungkinkan kawasan tersebut memiliki nilai strategis [1]. UI yang berada pada kawasan strategis di Kota Depok karena dilalui Jalan Margonda Raya sebagai jalan arteri sekunder [12]. Jalan Margonda Raya setiap tahunnya mengalami peningkatan volume pergerakan. Tercatat dalam data Dinas Perhubungan Kota Depok bahwa pada tahun [13], Jalan Margonda Raya telah mengalami peningkatan volume pergerakan sebesar $27,7 \%$ dari $37.390,3 \mathrm{smp} / j a m$ pada jam sibuk pagi, siang, dan malam hari [13]. Berdasarkan isu-isu yang ada dan ditunjang dengan teori serta data, maka diperlukan penelitian mengenai hubungan dan karakteristik pemanfaatan lahan dengan volume pergerakan di Jalan Margonda Raya, Kota Depok. Sehingga rumusan masalah dari penelitian ini adalah bagaimana hubungan dan karakteristik pemanfaatan lahan dengan sistem pergerakan di Jalan Margonda Raya, Kota Depok?

Penelitian ini memiliki kebaharuan dibandingkan penelitian-penelitian sebelumnya. Pada penelitian sebelumnya, pembahasan hanya mencakup mengenai kontribusi penggunaan lahan terhadap volume pergerakan. Penelitian ini tidak hanya membahas mengenai kontribusi terbesar tetapi juga menemukenali karakteristik dan hubungan antara pemanfaatan lahan dengan volume pergerakan.

\section{Metode penelitian}

Penelitian ini termasuk dalam penelitian kuantitatif dengan pendekatan deduktif. Variabel yang digunakan dalam penelitian ini terdiri atas dua aspek. Untuk lebih jelasnya dapat dilihat pada Tabel 1.

Tabel 1. Variabel penelitian

\begin{tabular}{|c|c|c|}
\hline Aspek & Variabel & Sub Variabel \\
\hline \multirow{11}{*}{$\begin{array}{l}\text { Aspek A: Pemanfaatan } \\
\text { Lahan di Sekitar Kawasan } \\
\text { Perguruan Tinggi }\end{array}$} & \multirow{3}{*}{ Perumahan } & Rumah Tinggal \\
\hline & & Indekos \\
\hline & & Apartemen \\
\hline & \multirow{3}{*}{ Komersil Area } & Kawasan Niaga \\
\hline & & Kawasan Jasa \\
\hline & & Pendidikan \\
\hline & \multirow{4}{*}{ Fasilitas Umum } & Peribadatan \\
\hline & & Kesehatan \\
\hline & & RTH \\
\hline & & Simpul Transportasi \\
\hline & Rekreasi & Rekreasi \\
\hline $\begin{array}{l}\text { Aspek B: Volume } \\
\text { Pergerakan }\end{array}$ & Volume Pergerakan & Volume Pergerakan \\
\hline
\end{tabular}


Pengumpulan data dilakukan dengan observasi dan traffic counting. Observasi dilakukan untuk mendapatkan data jenis pemanfaatan lahan pada kawasan penelitian. Sedangkan traffic counting dilakukan untuk mendapatkan data volume pergerakan kendaraan. Selanjutnya populasi dalam penelitian ini yaitu:

a. Luas kawasan penelitian sebesar 92,94 ha pada koridor Jalan Margonda segmen Jalan Ir. Juanda-Patung Salak (Gambar 1). Kawasan penelitian memiliki batasan fungsional yang didapatkan dari hasil delineasi tiga kriteria. Kriteria pertama dari luas kawasan yang terkena dampak dari keberadaan UI sejauh radius $500 \mathrm{~m}$ [6]. Kriteria kedua dari fungsi Jalan Margonda Raya sebagai jalan arteri yang memiliki pengaruh 500m pada kawasan sekitarnya [14]. Kriteria ketiga yaitu volume pergerakan tertinggi pada segmen-segmen Jalan Margonda Raya. Segmen Simpang Juanda - Simpang Patung Elang Salak pada Jalan Margonda Raya yang memiliki volume pergerakan tertinggi sebesar $18.401,4 \mathrm{smp} / \mathrm{jam}$ [15].

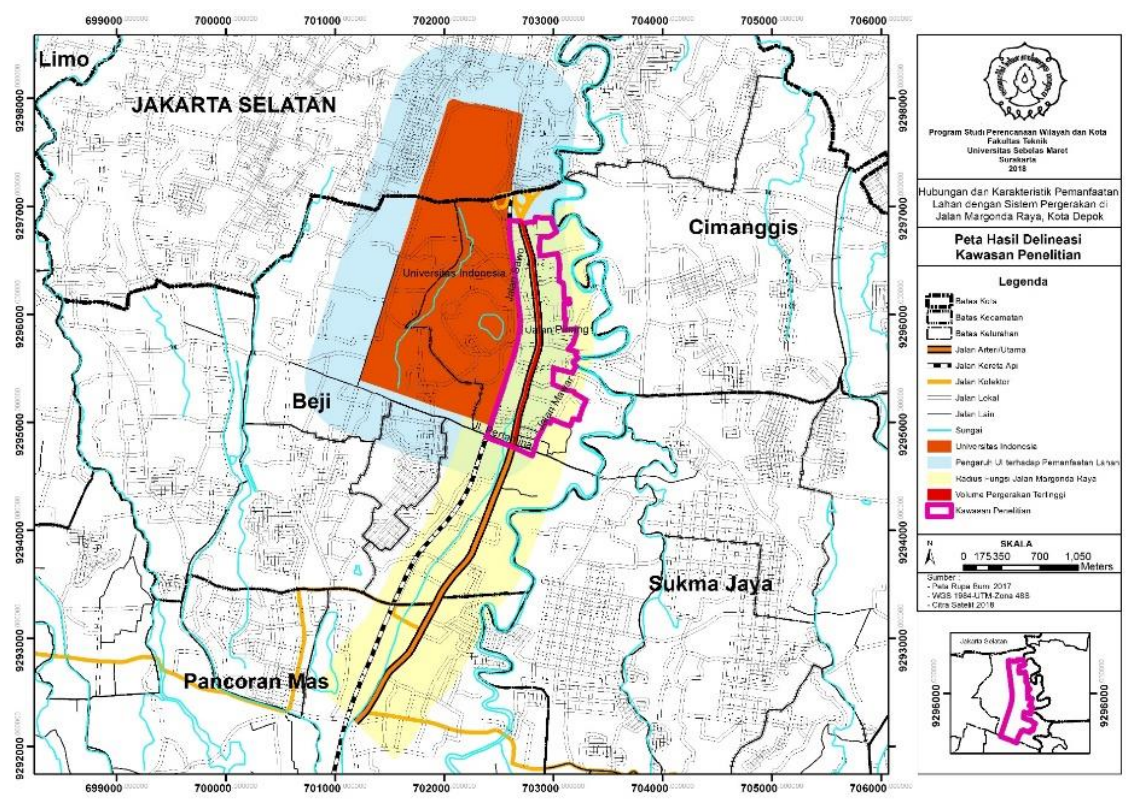

Gambar 1. Peta hasil delineasi kawasan penelitian

b. Jumlah kendaraan yang populasinya bersifat tak terhingga karena tidak dapat diidentifikasi.

c. Jenis kendaraan yang terbagi atas tiga jenis yaitu MC atau Motorcycle (kendaraan roda 2: sepeda motor), LV atau Light Vehicle (kendaraan roda 4: mobil, mini bus, pick up, truk kecil, dan jeep), dan HV atau Heavy Vehicle (kendaraan roda >4: truk dan bus) [16].

d. Titik traffic counting ditentukan dari zona-zona pemanfaatan lahan di kawasan penelitian, yang berjumlah 32 titik (Gambar 2). Traffic counting dilakukan pada pagi, siang, dan sore hari, baik ketika weekdays dan weekends. 

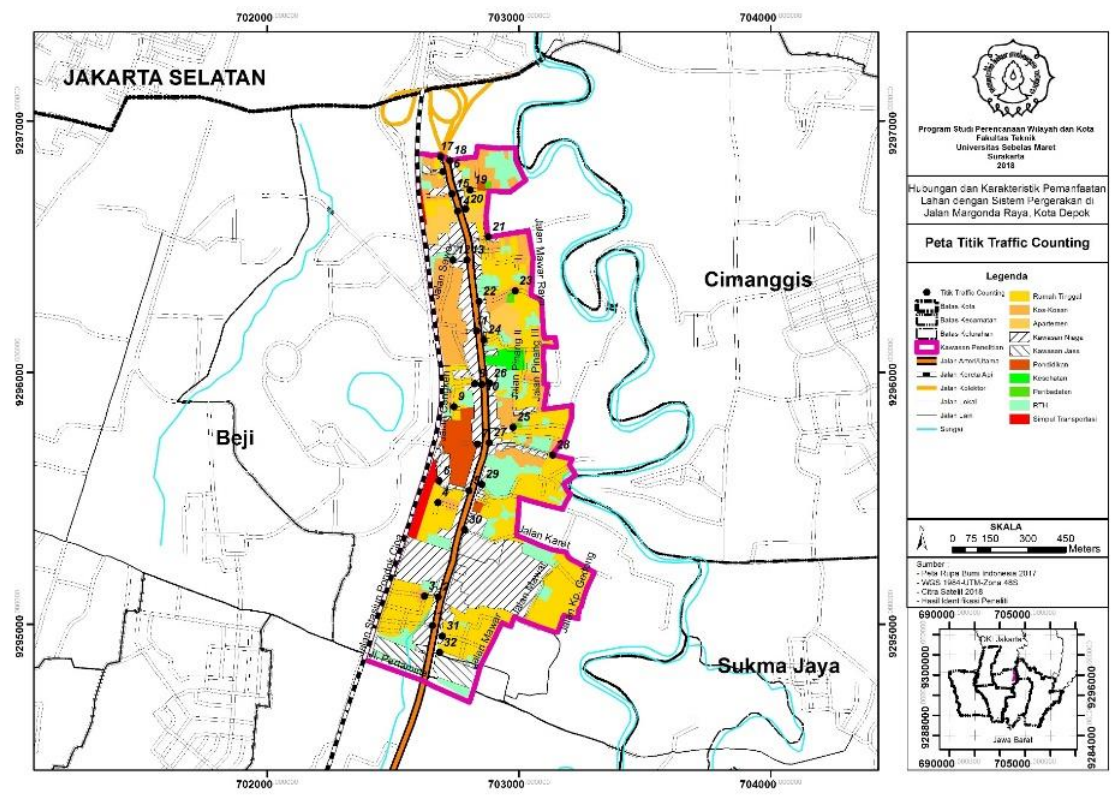

Gambar 2. Peta titik traffic counting

Data yang didapatkan dari hasil pengamatan selanjutnya diolah dan dianalisis untuk dapat menjawab pertanyaan penelitian dengan menggunakan teknik-teknik analisis pada Gambar 3.

\begin{tabular}{|c|c|c|c|c|}
\hline Sasaran & Input & \multicolumn{2}{|c|}{ Proses } & Output \\
\hline $\begin{array}{c}\text { Mengidentifikasi } \\
\text { karakteristik } \\
\text { pemanfaatan } \\
\text { lahan pada } \\
\text { koridor Jalan } \\
\text { Margonda Raya, } \\
\text { Kota Depok }\end{array}$ & $\begin{array}{l}\text { - Perumahan } \\
\text { - Komersil } \\
\text { - Frea } \\
\text { - Umulitas } \\
\text { - Rekreasi }\end{array}$ & $\begin{array}{c}\text { Analisis } \\
\text { Pemanfaatan } \\
\text { Lahan }\end{array}$ & Pemetaan dan & $\begin{array}{l}\text { Prosentase } \\
\text { Luas } \\
\text { Pemanfaatan } \\
\text { Lahan }\end{array}$ \\
\hline $\begin{array}{c}\text { Mengidentifikasi } \\
\text { karakteristik } \\
\text { Volume } \\
\text { Pergerakan } \\
\text { sepanjang Jalan } \\
\text { Margonda Raya, } \\
\text { Kota Depok }\end{array}$ & $\begin{array}{c}\text { Volume } \\
\text { Pergerakan }\end{array}$ & $\begin{array}{c}\text { Analisis } \\
\text { Volume } \\
\text { Pergerakan }\end{array}$ & $\begin{array}{c}\text { Volume Lalu } \\
\text { Lintas }\end{array}$ & $\begin{array}{c}\text { Volume } \\
\text { Pergerakan }\end{array}$ \\
\hline $\begin{array}{c}\text { Mengidentifikasi } \\
\text { hubungan dan } \\
\text { karakteristik } \\
\text { pemanfaatan } \\
\text { lahan dengan } \\
\text { Volume Lalu } \\
\text { Lintas di Jalan } \\
\text { Margonda Raya, } \\
\text { Depok }\end{array}$ & $\begin{array}{l}\text { - Prosentase } \\
\text { Luas } \\
\text { Pemanfaatan } \\
\text { Lahan } \\
\text { - Volume } \\
\text { Pergerakan }\end{array}$ & $\begin{array}{c}\text { Analisis } \\
\text { Hubungan }\end{array}$ & Korelasi dan & $\begin{array}{c}\text { Hubungan } \\
\text { dan } \\
\text { Karakteristik } \\
\text { Pemanfaatan } \\
\text { Lahan dengan } \\
\text { Volume } \\
\text { Pergerakan }\end{array}$ \\
\hline
\end{tabular}

Gambar 3. Kerangka analisis

\section{Hasil penelitian}

\subsection{Karakteristik pemanfaatan lahan}

Hasil pengamatan menunjukan hasil bahwa pemanfaatan lahan pada kawasan penelitian terdiri atas pemanfaatan lahan untuk rumah tinggal, indekos, apartemen, kawasan niaga, 
kawasan jasa, pendidikan, peribadatan, kesehatan, RTH, dan simpul transportasi. Untuk lebih jelasnya dapat dilihat pada Gambar 4.

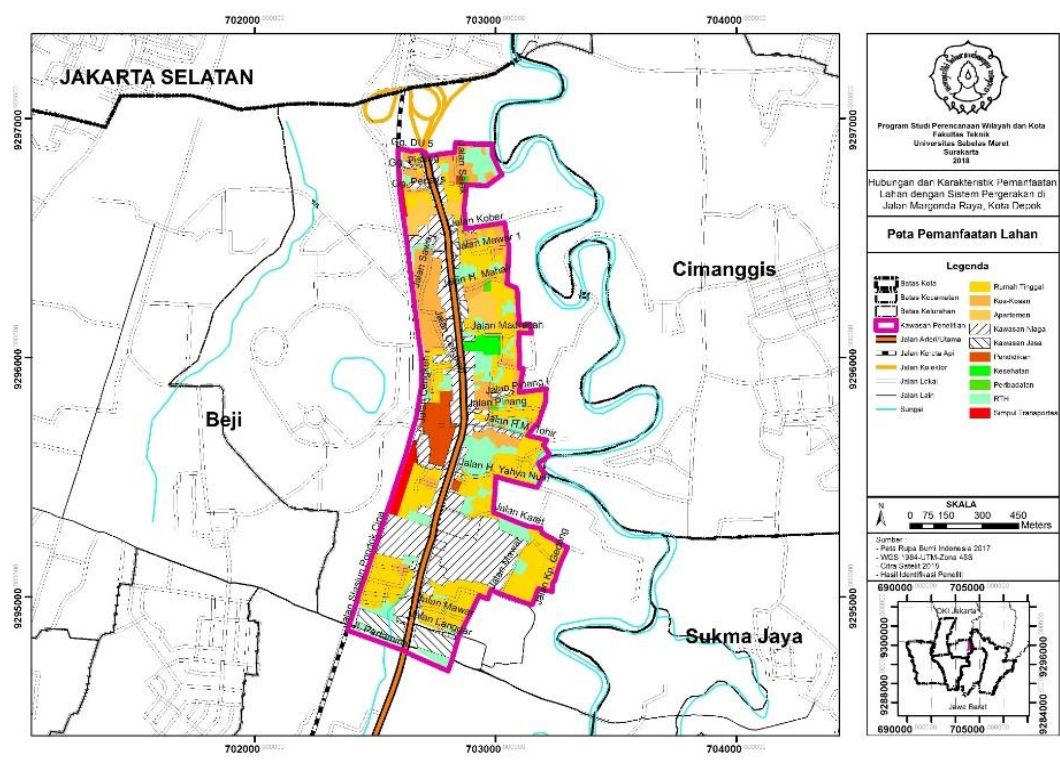

Gambar 4. Peta pemanfaatan lahan

Dari peta pemanfaatan lahan, luas pemanfaatan lahan dapat diidentifikasi dengan menggunakan aplikasi Arc GIS 10.1. Setelah mengetahui luas maka dilakukan perhitungan prosentase luasan pemanfaatan lahan. Untuk lebih jelasnya dapat dilihat pada Tabel 2.

Tabel 2. Luas dan prosentase pemanfaatan lahan

\begin{tabular}{clcc}
\hline No Jenis Pemanfaatan Lahan & $\begin{array}{c}\text { Luas Pemanfaatan Lahan } \\
\text { (ha) }\end{array}$ & $\begin{array}{c}\text { Prosentase Luas } \\
\text { Pemanfaatan Lahan }\end{array}$ \\
\hline 1 & Rumah Tinggal & 29,88 & $32 \%$ \\
2 & Indekos & 11,97 & $13 \%$ \\
3 & Apartemen & 2,98 & $3 \%$ \\
4 & Kawasan Niaga & 26,04 & $28 \%$ \\
5 & Kawasan Jasa & 3,54 & $4 \%$ \\
6 & Pendidikan & 3,48 & $4 \%$ \\
7 & Peribadatan & 0,4 & $0 \%$ \\
8 & Kesehatan & 1,02 & $1 \%$ \\
9 & RTH & 12,26 & $13 \%$ \\
10 & Simpul Transportasi & 1,37 & $2 \%$ \\
11 & Rekreasi & 0 & 0 \\
& & 90,16 & $100 \%$ \\
\hline
\end{tabular}

Kawasan penelitian merupakan kawasan yang berdampak atas keberadaan perguruan tinggi karena berdekatan lokasinya. Keberadaan perguruan tinggi menjadikan kawasan penelitian mengalami perkembangan. Perkembangan yang berlangsung dilihat dari segi spasial, yaitu perkembangan pemanfaatan lahan pada kawasan penelitian. Karena lokasi yang berdekatan dengan perguruan tinggi, menjadikan perkembangan pemanfaatan lahan di kawasan 
penelitian berfungsi untuk menunjang kebutuhan mahasiswanya. Sehingga pemanfaatan lahan di kawasan penelitian memiliki karakteristik pemanfaatan lahan yang berada di sekitar kawasan perguruan tinggi. Adanya indekos dan apartemen sebagai hunian bagi mahasiswa, serta pemanfaatan lahan komersial sebagai tempat-tempat usaha yang menyediakan atau menjual kebutuhan mahasiswanya, menjadi karakteristik yang paling kuat dari pemanfaatan lahan kawasan penelitian yang berada di kawasan perguruan tinggi. Sesuai dengan teori yang dikemukakan oleh Munggiarti \& Buchori [6], bahwa pemanfataan lahan sekitar kawasan perguruan tinggi memiliki karakteristik seputar untuk rumah tinggal, indekos, dan tempat usaha. Sedangkan lokasi kawasan penelitian yang berada di pusat Kota Depok, mengakibatkan semakin sedikit lahan kosong yang berada di kawasan penelitian. Untuk memenuhi kebutuhan tempat tinggal mahasiswanya, maka di kawasan penelitian terdapat beberapa apartemen untuk meminimalisir sedikitnya lahan yang tersedia. Sesuai dengan teori Priambudi \& Pigawati [17], bahwa apartemen menjadi inovasi dalam efisiensi pemenuhan kebutuhan tempat tinggal pada lahan yang terbatas.

Sebagai bagian dari kota satelit dari DKI Jakarta, pemanfaatan lahan kawasan penelitian termasuk ke dalam jenis dari urban land uses, sehingga menyebabkan pemanfaatan lahan kawasan penelitian beragam dengan sifat kekotaan. Hal ini sesuai dengan mengacu pada teori dari Yunus [18], bahwa pemanfaatan lahan urban land uses diperuntukan untuk pemanfaatan lahan kepentingan sektor kekotaan. Sifat kekotaan pada pemanfaatan lahan dilihat dari pada sisi kanan-kiri Jalan Margonda Raya yang dimanfaatkan untuk lahan kawasan niaga dan kawasan jasa. Pada sisi timur Jalan Margonda Raya dimanfaatakan untuk perumahan. Pemanfaatan lahan kesehatan, peribadatan, dan pendidikan yang lokasinya tersebar di kawasan penellitian menyesuaikan kebutuhan dari penduduk. Satu karakteristik utama yang berada pada kawasan penelitian yaitu terdapat pemanfaatan lahan untuk simpul transportasi karena lokasi kawasan penelitian yang berada pada pusat Kota Depok sehingga mudah untuk dijangkau dari berbagai daerah di Kota Depok. Hal ini didukung dengan teori dari Zulkifli [19], bahwa karakteristik pemanfaatan lahan kota didominasi untuk pemanfaatan lahan permukiman, bangunan umum, dan keperluan sosial.

\subsection{Karakteristik volume pergerakan}

Setelah dilakukan analisis berdasarkan hasil traffic counting, analisis menunjukan hasil bahwa setiap pemanfaatan lahan memiliki karakteristik yang berbeda-beda, sehingga volume pergerakan yang dihasilkan menunjukan hasil yang beragam. Volume pergerakan terjadi dikarenakan adanya bangkitan-tarikan pergerakan pada suatu pemanfaatan lahan. Faktor utama yang menjadi penentu dalam tinggi rendahnya volume pergerakan yang dihasilkan pada suatu pemanfaatan lahan ditentukan atas aktivitas yang berlangsung pada pemanfaatan lahan tersebut. 


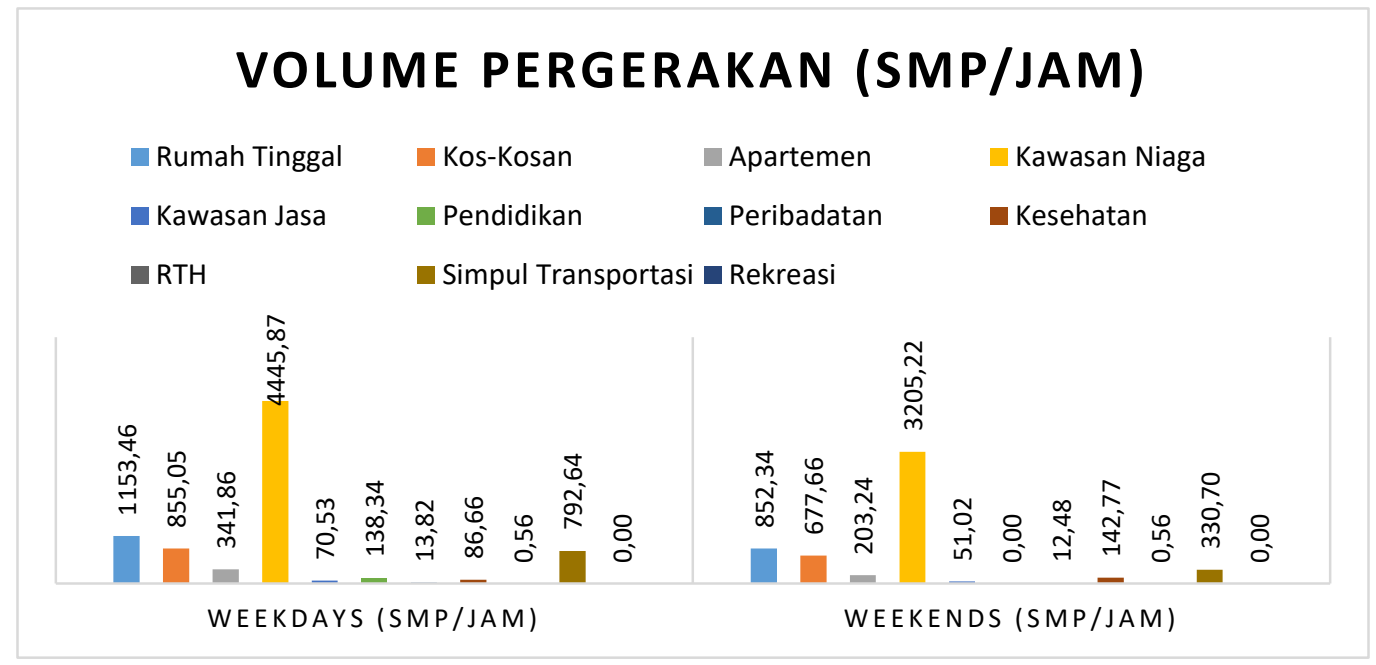

Gambar 5. Diagram volume pergerakan kawasan penelitian

Pemanfaatan lahan kawasan niaga memiliki volume pergerakan tertinggi, baik ketika weekdays maupun weekends sebagaimana digambarkan pada Gambar 5. Selanjutnya volume pergerakan tertinggi kedua hingga kelima baik ketika weekdays maupun weekends berada pada pemanfaatan lahan rumah tinggal, pemanfaatan lahan indekos, pemanfaatan lahan simpul transportasi, pemanfaatan lahan apartemen. Untuk volume pergerakan weekdays, volume pergerakan tertinggi lainnya diikuti pada pemanfaatan lahan pendidikan, pemanfaatan lahan kesehatan, pemanfaatan lahan kawasan jasa, pemanfaatan lahan peribadatan, dan pemanfaatan lahan RTH. Sedangkan untuk volume pergerakan weekends, volume pergerakan tertinggi pada pemanfaatan lahan kesehatan, pemanfaatan lahan kawasan jasa, pemanfaatan lahan peribadatan, dan pemanfaatan lahan RTH.

Volume pergerakan tertinggi di kawasan penelitian berada pada pemanfaatan lahan kawasan niaga. Hal ini sesuai dengan pernyataan Tamin [10], bahwa pemanfaatan lahan kawasan niaga merupakan pemanfaatan lahan dengan volume pergerakan tertinggi karena banyak aktivitas didalamnya. Pemanfaatan lahan kawasan niaga menjadi pemanfaatan lahan dengan volume pergerakan tertinggi karena memiliki karakteristik yaitu banyaknya aktivitas yang berlangsung pada pemanfaatan lahan kawasan niaga sehingga meningkatkan volume pergerakan.

Setiap volume pergerakan yang dihasilkan pada suatu pemanfaatan lahan memiliki waktu puncak yang berbeda. Ketika weekdays dan weekends, seperti pada pemanfaatan lahan rumah tinggal, pemanfaatan lahan indekos, pemanfaatan lahan apartemen, dan pemanfaatan lahan kawasan niaga, volume pergerakan tertinggi terjadi pada sore hari. Pada pemanfaatan lahan kawasan jasa, volume pergerakan tertinggi terjadi pada sore hari ketika weekdays dan siang hari ketika weekends. Volume pergerakan tertinggi di pemanfaatan lahan kawasan pendidikan, terjadi pada siang hari ketika weekdays. Untuk pada pemanfaatan lahan peribadatan, volume pergerakan tertinggi terjadi pada siang hari ketika weekdays dan pagi hari ketika weekends. Pada pemanfaatan lahan kesehatan, volume pergerakan tertinggi terjadi pada pagi hari ketika weekdays dan siang hari ketika weekends. Sedangkan 
pemanfaatan lahan RTH dan simpul transportasi, volume pergerakan tertinggi terjadi pada pagi hari baik ketika weekends maupun weekdays.

Waktu puncak volume pergerakan berbeda pada masing-masing pemanfaatan lahan tersebut tentunya dikarenakan karakteristik dari pemanfaatan lahan tersebut. Karakteristik yang ada pada pemanfaatan lahan rumah tinggal, pemanfaatan lahan indekos, pemanfaatan lahan apartemen, dan pemanfaatan lahan kawasan niaga seperti sore hari menjadi waktu sibuk dikarenakan penduduk yang selesai beraktivitas untuk kembali ke tempat tinggalnya masingmasing atau sekedar singgah pada pemanfaatan lahan kawasan niaga, serta menjadi waktu yang dipilih penduduk untuk beraktivitas keluar rumah pada weekends. Sedangkan karakteristik yang ada pada pemanfaatan lahan kawasan jasa seperti aktivitas yang berlangsung memiliki keterbatasan waktu, sehingga siang hari menjadi waktu puncak karena sebagai jam istirahat penduduk dari aktivitas utamanya.

Untuk karakteristik pada pemanfaatan lahan pendidikan seperti siang hari volume pergerakan yang dihasil lebih tinggi karena menjadi waktu dalam aktivitas mengantar dan menjemput anak sekolah, berbeda pada pagi hari yang hanya menjadi aktivitas mengatar anak sekolah dan sore hari yang hanya menjadi aktivitas menjemput anak sekolah. Karakteristik pada pemanfaatan lahan peribadatan yaitu kedua waktu tersebut menjadi tempat persinggahan bagi pengguna jalan di sekitar pemanfaatan lahan tersebut.

Karakteristik yang menjadi waktu puncak pada pemanfaatan simpul transportasi yaitu banyaknya penduduk Kota Depok yang menjadi komuter atau bekerja di kota-kota sekitarnya. Sehingga sebelumnya melakukan pergerakan menuju pemanfaatan lahan simpul transportasi dengan menggunakan kendaraan pribadi. Hal ini sesuai dengan teori yang dikemukakan oleh Tamin [8], bahwa setiap pemanfaatan lahan memiliki masing-masing karakteristik sehingga terjadi perbedaan waktu dalam volume pergerakan tertinggi yang dihasilkan.

\subsection{Hubungan dan karakteristik pemanfaatan lahan dengan volume pergerakan}

Untuk mencari tahu hubungan dan karakteristik pemanfaatan lahan dengan volume pergerakan digunakan analisis korelasi Pearson. Analisis korelasi pada penelitian ini dilakukan dengan menggunakan software SPSS 25.

Tabel 3. Analisis korelasi pemanfaatan lahan dengan volume pergerakan weekdays

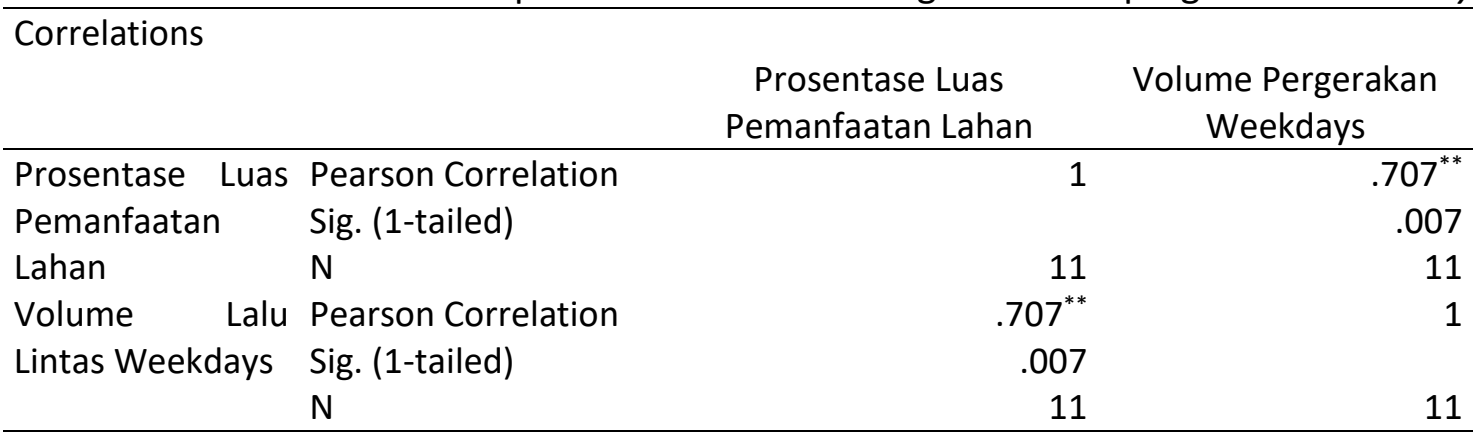

**. Correlation is significant at the 0.01 level (1-tailed). 
Hasil analisis korelasi menunjukan bahwa hubungan antara volume pergerakan weekdays dengan prosentase luas pemanfaatan lahan memiliki hubungan yang kuat, ditunjukan dengan nilai koefisien korelasi sebesar 0,707 (Tabel 3). Nilai positif yang ditunjukan dari hasil analisis menunjukan bahwa hubungan keduanya dikatakan searah. Menurut teori yang ada, koefisien korelasi jika mendekati angka 1 (satu) maka akan semakin kuat serta jika menunjukan hasil posifif maka kedua variabel memiliki hubungan yang searah [20]. Hubungan diantara kedua variabel memiliki hubungan yang signifikan karena menunjukan nilai signifikasi (sig. I-tailed) yaitu 0,007 atau memiliki nilai signifikasi (sig. l-tailed) $<0,01$.

Tabel 4. Analisis korelasi pemanfaatan lahan dengan volume pergerakan weekends

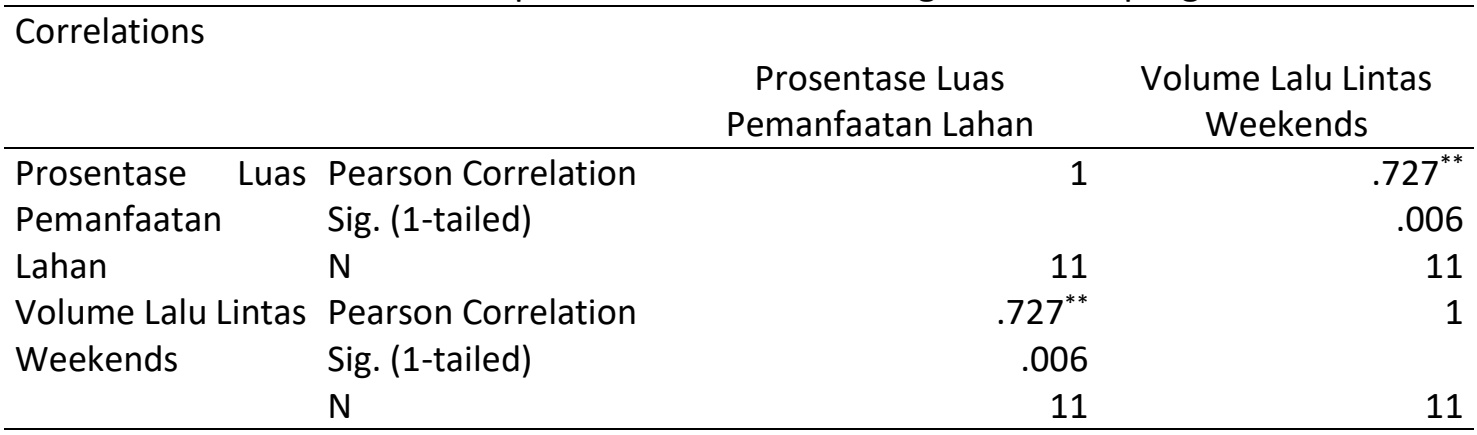

**. Correlation is significant at the 0.01 level (1-tailed).

Hasil analisis korelasi menunjukan bahwa hubungan yang kuat terjadi antara variabel volume pergerakan weekends dengan prosentase luas pemanfaatan lahan. Hal ini bisa dilihat dengan nilai koefisien korelasi yang dimiliki sebesar 0,727 (Tabel 4). Nilai positif yang ditunjukan dari hasil analisis menunjukan bahwa hubungan antara keduanya dikatakan searah. Serta hubungan antar-variabel memiliki hubungan yang signifikan yang bisa dilihat dari hasil analisis yang menunjukan nilai signifikasi (sig. I-tailed) yaitu 0,006 atau memiliki nilai signifikasi (sig. Itailed) $<0,01$.

Pemanfataan lahan dengan volume pergerakan baik ketika weekdays dan weekends yang tejadi di kawasan penelitian memiliki hubungan yang kuat. Hubungan tersebut dikarenakan pemanfaatan lahan yang luas pada kawasan penelitian menimbulkan volume pergerakan yang tinggi. Hasil analisis menunjukan hasil yang sesuai dengan teori yang dikemukakan oleh Tamin [10], bahwa volume pergerakan dengan pemanfaatan lahan memiliki korelasi yang positif. Hasil analisis menunjukan bahwa ketiga pemanfaatan lahan terluas, yaitu pemanfaatan lahan rumah tinggal, kawasan niaga, dan indekos, juga memiliki volume pergerakan yang paling tinggi. Hal ini sesuai dengan teori yang dikemukakan oleh Budi [11], bahwa semakin luasnya suatu pemanfaatan lahan, volume pergerakan yang dihasilkan juga semakin tinggi.

Pemanfaatan lahan kawasan niaga dengan prosentase luas pemanfaatan lahan terbesar kedua memiliki volume pergerakan paling tinggi, baik ketika weekdays dan weekends. Karakteristik dari pemanfaatan lahan ini yaitu pergerakan yang berlangsung terjadi dengan cepat serta letaknya yang berada di jalan utama Kota Depok, sehingga akses yang mudah untuk menuju pemanfaatan lahan ini. Kedua hal tersebut menimbulkan volume pergerakan yang dihasilkan menjadi tinggi. Hal ini sesuai dengan teori yang dikemukakan oleh Abdusomad 
[1], bahwa tingginya volume pergerakan yang dihasilkan pada pemanfaatan lahan yang berada pada jalan utama. Seperti pemanfaatan lahan yang berada pada sisi kanan-kiri Jalan Margonda Raya yang berupa toko-toko. Pemanfaatan lahan tersebut tidak memiliki lahan yang terlalu luas namun volume pergerakan yang dihasilkan tinggi dikarenakan perputaran pergerakan antar-pembeli yang berdatangan berlangsung cepat.

Namun beberapa pemanfaatan lahan kawasan niaga pada kawasan penelitian memiliki pemanfaatan lahan yang luas sehingga menjadikan aktivitas yang berada didalamnya lebih banyak dan menjadi daya tarik tersendiri untuk penduduk melakukan pergerakan. Sesuai dengan teori yang dikemukakan Tamin [10], bahwa luas pemanfaatan lahan yang besar menjadikan aktivitas yang berada didalamnya lebih banyak.

Pemanfaatan lahan rumah tinggal dengan prosentase luas pemanfaatan lahan terbesar memiliki volume pergerakan tertinggi kedua, baik ketika weekdays dan weekends. Kawasan penelitian memiliki nilai strategis di pusat Kota Depok, sehingga terjadi perkembangan pemanfaatan lahan rumah tinggal. Hal tersebut menyebabkan pemanfaatan lahan rumah tinggal masih mendominasi sebagai pemanfaatan lahan terluas di kawasan penelitian dan mempengaruhi bangkitan pergerakan. Pemanfaatan lahan rumah tinggal memiliki bangkitan pergerakan terbesar.

Karakteristik bangkitan terbesar yang ditimbulkan dari pemanfaatan lahan rumah tinggal yaitu banyaknya aktivitas penduduk (meliputi aktivitas sosial, aktivitas ekonomi maupun aktivitas pada simpul transportasi). Sehingga penduduk berpindah dari pemanfaatan lahan rumah tinggal ke pemanfaatan lahan lainnya untuk memenuhi aktivitasnya. Pemanfaataan lahan lainnya menjadi bangkitan dari pergerakan yang dilakukan penduduk pada kawasan penelitian. Pernyataan ini sesuai dengan teori yang dikemukakan oleh Abdusomad [1], bahwa perkembangan pesat pada suatu kawasan yang melibatkan aspek pemanfaatan lahan memungkinkan kawasan tersebut memiliki nilai strategis, sehingga terjadi fenomena pergerakan penduduk menuju kawasan tersebut, mengakibatkan timbulnya tarikan yang besar pada pemanfaatan lahan di kawasan tersebut.

Pemanfaatan lahan indekos dengan prosentase luas pemanfaatan lahan terbesar ketiga memiliki volume pergerakan tertinggi ketiga, baik ketika weekdays dan weekends. Menjadi pemanfaatan lahan dengan prosentase luas pemanfaatan lahan terbesar ketiga dikarenakan kawasan penelitian sebagai kawasan yang terkena dampak dari kawasan perguruan tinggi. Sedangkan pemanfaatan lahan apartemen memiliki volume pergerakan tertinggi kelima, baik ketika weekdays dan weekends walaupun prosentase luas pemanfaatan lahan yang tidak begitu besar.

Pemanfaatan lahan indekos dan apartemen sebagai bentuk pemenuhan hunian para mahasiswa. Hal ini sesuai dengan teori dari Munggiarti \& Buchori [6], bahwa karakteristik pemanfataan lahan sekitar kawasan perguruan tinggi seputar untuk pemanfaatan lahan indekos serta teori dari Priambudi \& Pigawati [17], bahwa apartemen menjadi bagian dalam pemenuhan kebutuhan tempat tinggal bagi mahasiswa. Tingginya volume pergerakan pada pemanfaatan lahan indekos dan apartemen dikarenakan banyaknya aktivitas yang dilakukan 
mahasiswa, yang tidak hanya untuk pergi atau dari kampus, namun mahasiswa juga memiliki aktivitas-aktivitas lainnya.

Pemanfaatan lahan simpul transportasi memiliki volume pergerakan tertinggi keempat, baik ketika weekdays walaupun memiliki prosentase luas pemanfaatan lahan yang tidak begitu luas. Pemafaatan lahan ini berfungsi sebagai tempat transit, sehingga pergerakan yang dilakukan penduduk berlangsung dengan cepat, maka tingginya volume pergerakan yang dihasilkan.

Pemanfaatan yang memiliki volume pergerakan berikutnya yaitu pendidikan, kesahatan, kawasan jasa, peribadatan, dan RTH yang tidak memiliki karakteristik khusus. Pemanfaatan lahan ini hanya sebagai penunjang kebutuhan penduduk pada kawasan penelitian. Rendahnya volume pergerakan yang dihasilkan pada pemanfaatan lahan ini dikarenakan sedikitnya aktivitas yang berada pada pemanfaatan lahan ini. Hal ini sesuai dengan teori Yunus [18], bahwa semakin banyak penduduk memiliki aktivitas, maka semakin sering penduduk melakukan pergerakan untuk memenuhi kebutuhannya.

\section{Kesimpulan}

Kawasan penelitian merupakan kawasan yang terkena dampak dari keberadaan perguruan tinggi. Berpindahnya UI dari Jakarta ke Depok mengakibatkan kawasan sekitar UI mengalami perkembangan. Perkembangan meliputi dua aspek yaitu aspek pemanfaatan lahan dan aspek sistem pergerakan. Kedua aspek tersebut merupakan aspek yang saling berhubungan, sehingga jika salah satu mengalami perkembangan maka berdampak pada aspek lainnya.

Pemanfaatan lahan pada kawasan penelitian mengalami perkembangan yang cukup sigifikan. Perkembangan tersebut menjadikan pemanfaatan lahan kawasan penelitian memiliki karakteristik-karakteristik tertentu. Berdasarkan hasil analisis, pemanfaatan lahan kawasan penelitian memiliki karakteristik khusus karena sebagai kawasan yang dekat dengan perguruan tinggi. Sehingga pemanfaatan lahan berorientasi kepada pemenuhan kebutuhan untuk mahasiswa. Karakteristik pemanfaatan lahan pada kawasan penelitian juga dikarenakan kawasan penelitian sebagai bagian dari kota satelit DKI Jakarta, sehingga orientasi pemanfaatan lahan temasuk kedalam urban land uses.

Volume pergerakan pada masing-masing pemanfaatan lahan ditentukan atas lokasi pemanfaatan lahan serta jenis kendaraan yang digunakan. Kedua hal ini akan mempengaruhi pergerakan yang dilakukan penduduk menuju pemanfaatan lahan tersebut. Setiap volume pergerakan yang dihasilkan pada masing-masing pemanfaatan lahan memiliki perbedaan waktu puncak. Kedua hal tersebut dikarenakan masing-masing pemanfaatan lahan memiliki karakteristik.

Pemanfaatan lahan dengan volume pergerakan weekdays dan weekends menunjukan hasil bahwa kedua hal tersebut memiliki hubungan yang kuat dengan korelasi positif. Hubungan tersebut didasarkan pada karakteristik pemanfaaatan lahan yang semakin beragam dan semakin luas, maka volume pergerakan yang dihasilkan juga semakin tinggi, dikarenakan aktivitas juga semakin beragam. 


\section{Referensi}

[1] Abdusomad M 2004 Pola Pengaruh Penggunaan Lahan Terhadap Sistem Pergerakan pada Kawasan Pusat Kota Brebes Tesis Semarang: Universitas Diponegoro Diakses dari http://eprints.undip.ac.id/5102/

[2] Badan Pusat Statistik Kota Depok 2016 Kota Depok Dalam Angka 2016 Diakses dari https://depokkota.bps.go.id/publication/2018/01/05/fad2cf64650af0e3875243c6/k ota-depok-dalam-angka-2016.html

[3] Badan Pusat Statistik Kota Depok 2017 Kota Depok Dalam Angka 2017 Diakses dari https://depokkota.bps.go.id/publication/2018/01/11/725583139ac8386b2925a7d9 kkota-depok-dalam-angka-2017.html

[4] Sutardi S D 2003 Perubahan Fungsi Ruang di Jalan Margonda Raya Sekitar Kawasan Pendidikan Tesis (Depok: Universitas Indonesia)

[5] Amiruddin A 2014 Pengaruh Keberadaan Universitas Haluoleo Terhadap Perubahan Tata Guna Lahan di Kawasan Andonuohu Kota Kendari Jurnal Wilayah dan Lingkungan 2 73-88 DOI: 10.14710/jwl.2.1.73-88

[6] Munggiarti A dan Buchori I 2015 Pengaruh Keberadaan Perguruan Tinggi Terhadap Perubahan Morfologi Kawasan Sekitarnya Journal of Geomatics and Planning 2 5168 DOI: 10.14710/geoplanning.2.1.51-68

[7] Pratiwi A dan Ihsannudin 2016 Dampak Keberadaan Kampus Universitas Trunojoyo Madura Terhadap Nilai Tanah yang Ada di Sekitarnya Media Trend 11 52-68 DOI: 10.21107/mediatrend.v11i1.1355

[8] Tamin O Z 1997 Perencanaan dan Pemodelan Transportasi Bandung: ITB Bandung

[9] Julianto E N 2010 Hubungan Antara Kecepatan, Volume dan Kepadatan Lalu Lintas Ruas Jalan Siliwangi Semarang Jurnal Tekik Sipil \& Perencanaan 12 151-60 Diakses dari https://journal.unnes.ac.id/nju/index.php/itsp/article/view/1348 pada 5 Desember 2017

[10] Tamin O Z 2000 Perencanaan dan Pemodelan Transportasi (Bandung: ITB Bandung)

[11] Budi I S 2000 Pengaruh Penggunaan Lahan Terhadap Bangkitan dan Tarikan Pergerakan di Sepanjang Jalan Gadjah Mada Kota Batam Tesis (Semarang: Universitas Diponegoro) Diakses dari http://eprints.undip.ac.id/15654/

[12] Pemerintah Kota Depok 2015 Peraturan Daerah Kota Depok No. 1 Tahun 2015 tentang Rencana Tata Ruang Wilayah Kota Depok 2012-2032 Lembar Daerah Kota Depok Tahun 2015 No. 1

[13] Dinas Perhubungan Kota Depok 2015 Tatralok Kota Depok 2015

[14] Li S et al 2004 Statistical Analysis on The Relationship between Road Network and Ecosystem Fragmentation in China China Academic Journal 23 78-86 Diakses dari http://en.cnki.com.cn/Article en/CJFDTOTAL-DLKJ200405009.htm pada 2 November 2017

[15] Dinas Perhubungan Kota Depok 2017 Tatralok Kota Depok 2017

[16] Direktorat Jendral Bina Marga 1997 Manual Kapasitas Jalan Indonesia (MKJI) Jakarta: Direktorat Jendral Bina Marga

[17] Priambudi B N dan Pigawati B 2014 Faktor-Faktor Yang mempengaruhi Perubahan Pemanfaatan Lahan dan Sosial Ekonomi di Sekitar Apartemen Mutiara Garden Jurnal 
$\begin{array}{llllll}\text { Teknik } & P W K & 3 & 576-84 & \text { Diakses dari }\end{array}$ https://ejournal3.undip.ac.id/index.php/pwk/article/view/6680 pada 8 April 2014

[18] Yunus H S 2008 Dinamika Wilayah Peri-Urban: Determinan Masa Depan Kota (Yogyakarta: Pustaka Pelajar)

[19] Zulkifli A 2015 Pengelolaan Kota Berkelanjutan (Yogyakarta: Graha Ilmu)

[20] Purwanto E A dan Sulistyastuti D R 2011 Metode Penelitian Kuantitatif: Untuk Administrasi Publik dan Masalah-Masalah Sosial Edisi 2 (Yogyakarta: Gava Media) 